\title{
成形品へ及ぼすノズル通過樹脂温度挙動の影響
}

\author{
西脇信彦*・今野政昭*・崔 愛玲*・橋本展明*・堀 三計*

\section{Influence of the Injected Resin Temperature Behavior through the Nozzle on Moldings}

\author{
Nobuhiko Nishiwaki*, Masaaki Konno*, Ailing CuI*, \\ Nobuaki Hashimoro*, Sankei HoRI*
}

\begin{abstract}
When crystalline thermoplastic is used as an injected material, the crystallinity of the moldings depends on the cooling rate of the resin in the cavity. Therefore, a number of CAE software packages for simulating the cooling behavior of the filled resin have been developed, by assuming constant temperature of the resin through the nozzle. On the other hand, it is clear that the temperature of the resin injected from the nozzle into the cavity is not always constant. Moreover, the influence of the temperature variation of the injected resin on the crystallinity distribution in the moldings has not also been made clear.

In this paper, the temperature behavior of the resin injected into the cavity was related to the barrel temperature distribution and nozzle temperature. It is clear that the crystallinity distribution of the molded resin depends on the temperature behavior of the injected resin. From these experimental results, it is clear that the crystallinity distribution of the molded resin becomes nearly constant when the injected resin temperature through the nozzle is high at the initial injection stage, and becomes low after the initial stage.
\end{abstract}

Key Words : Injected resin temperature/Cooling behavior/Crystallinity distribution

\section{1. 緒言}

結晶性樹脂を用いた射出成形加工においては，成形 品の結晶化度を均一化することが成形品のそりを防止 するうえで重要となる．結晶化度を均一化するために

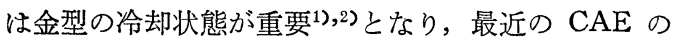

* 東京農工大学 工学部 機械システム工学科

小金井市中町 2-24-16 (广184)

Department of Mechanical Systems Engineering,

College of Engineering, Tokyo University of

Agriculture and Technology

2-24-16 Naka-cho, Koganei, Tokyo 184, Japan

1993. 8. 7 受理
解析でもとり解析が盛しに行われるようになってき

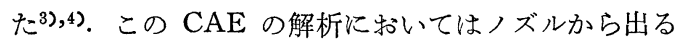
樹脂が一定温度であると仮定して解析が行われてい る.しかし，実際にはノズルから射出される樹脂温度 は変動することが知られている5゙. したがって，ノズ ルから射出される樹脂の温度変動が, 成形品の品質の 一つである結晶化度の分布へ及ぼす影響については解 析的にも実験的にも未だ充分解明されていないのが現 状である.

そこで本研究では，ノズルから金型へ充填される樹 脂温度の变動挙動が, 成形品の冷却・固化状態に及ぼ す影響, さらに, 成形品の品質の一つである結晶化度 


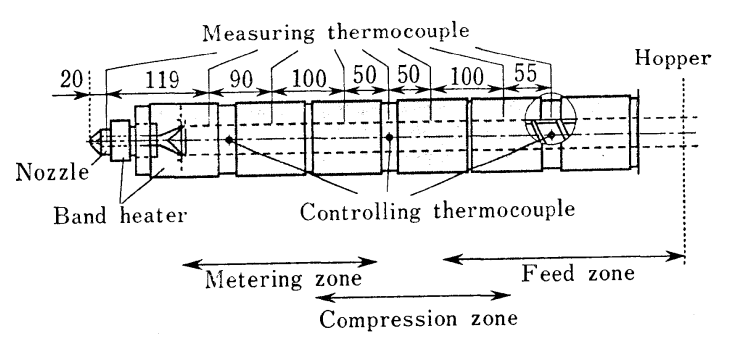

Fig. 1 Experimental apparatus

(All dimensions are in $\mathrm{mm}$ )

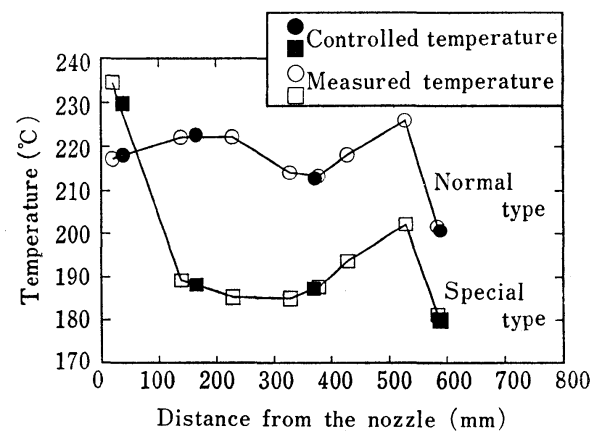

Fig. 3 Barrel temperature distribution

へ及ぼす影響について調べた．具体的には，射出成形 機のノズル温度およびバレルの温度分布を変化させる ことにより，ノズルから射出される樹脂温度を変化さ せて, そのノズル流出樹脂温度の变化が成形中の冷却 挙動や成形後の成形品の結晶化度に及ぼす影響を調べ た. その結果，ノズル樹脂温度の挙動を変えることに より，成形品の結晶化度分布が改善できることを明ら かにした、なお，ノズルから金型へ充媜される樹脂温 度の代表值としては，ノズル中心を流れる樹脂の温度 を熱電対で測定した值を用いた。

\section{2. 実験方法および結果}

\section{1 実 験 装 置}

ノズル内の溶融樹脂の流速分布を考慮すると, 金型 へ充填される樹脂の大部分はノズルの中心付近を流れ る溶融樹脂であると考えられる.したがって，その部 分の温度を測定すれば充埧される樹脂の代表温度を示 していると考えられる. そこで, 射出中の樹脂の温度 挙動を直接測定するために直径 $0.5 \mathrm{~mm}$ のシース型熱 電対をノズル流路内の中心に流れ方向に沿って吹き流 し状に挿入して測定した.なお，溶融樹脂と熱電対の 間ではせん断発熱が生じると考学られるが，熱電対測 温部を下流側に置くことで，せん断発熱による加熱を 受けた後の樹脂温度を測定していることになり，測定
Cavity

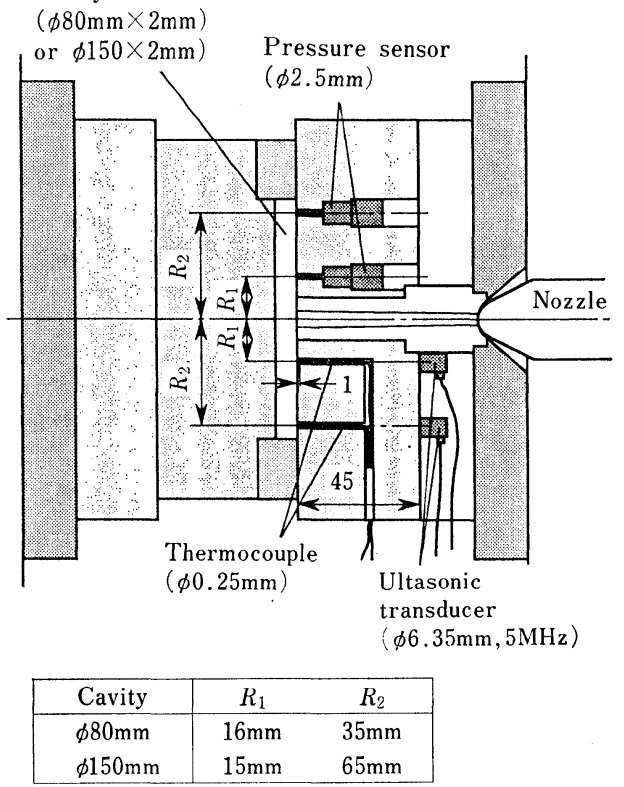

Fig. 2 Experimental apparatus

された温度は実際に充媜される樹脂温度の代表值を示 していると考えることができる．また，ノズル部の温 度はノズル部に埋め込まれた熱電対で，バレル部の温 度は軸方向に 3 個所埋め込まれた熱電対で測定し，そ れらの熱電対の值が設定温度になるようにノズル部と バレル部の外周面に巻かれた電気ヒーターの発熱量を 制御している.

本実験で使用したバレル部の概略を Fig. 1 に示す. この図に示されるように，温度制御用の熱電対の他に 測定用熱電対をバレルに埋め込み，その温度分布を測 定した.

使用した射出成形機は新潟鉄工所製 AN 50 で. ス クリュ径は $35 \mathrm{~mm}, L / D=18$ のコンベンショナルフ ルフライトスクリュ，最大射出容量は $96 \mathrm{~cm}^{3}$ である.

Fig. 2 に示すよらに金型キャビティ形状としては, ノズルから射出される樹脂の温度変化の影響を充分把 握できるように，直径 $150 \mathrm{~mm}$ ，厚さ $2 \mathrm{~mm}$ の円盤状 （容量：約 $35 \mathrm{~cm}^{3}$ ）を用いた. 成形の中のキャビティ 内圧力挙動を測定するため，固定側金型にはキャビテ ^の中心から $15 \mathrm{~mm}, 65 \mathrm{~mm}$ の位置に先端径 $2.5 \mathrm{~mm}$ の水晶圧電式圧力センサー(KISTLER 製 $6159 \mathrm{~A})$ を 取り付けた。 また，樹脂から金型へ流入する熱量を求 めるため, 同じ半径位置でキャビティ表面から $1 \mathrm{~mm}$ の位置に直径 $0.25 \mathrm{~mm}$ のシース形熱電対を取り付け た.さらに，キャビティ内に充填された樹脂へ超音波 を投射し，キャビティ内の樹脂温度挙動や固化層の発 


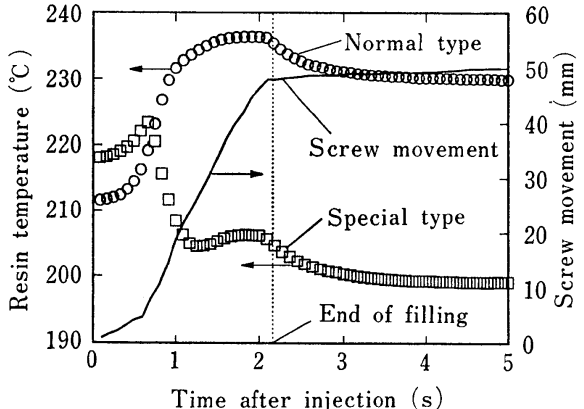

Fig. 4 Behavior of injected resin temperature (Cavity shape $=\phi 150 \mathrm{~mm}$ )

達挙動を観察するため，移動側金型外表面に縦波超音 波送受信子を取り付けた。

超音波送受信子は周波数 $5 \mathrm{MHz}$ ，振動子外径 6.35 mm (PANAMETRICS 製 M 110) でキャビティ内半 径 $15 \mathrm{~mm}$ ， 65mm の位置で測定できるようにした。 な拉，射出量が小さい場合でもノズルから射出される 樹脂温度変動の影響を確認するため, 直径 $80 \mathrm{~mm}$ で 厚さ $2 \mathrm{~mm}$ の円盤状 (容量: 約 $10 \mathrm{~cm}^{3}$ ) の金型も使用 した. 本実験で使用した樹脂は高密度ポリエチンン (HDPE) である.

\section{2 実験方法}

バレルの設定温度として樹脂メーカーが推奖するよ らな值を用いると，Fig. 3 の○印や○印に示すような 温度分布となる.なお同図の印はバレル外周面に巻 かれたヒーター加熱量を制御するための熱電対による 值であり，○印はバレルの温度分布を測定するため， 新たに取り付けられた熱電対による值である。その 時，ノズルから流出する樹脂温度の挙動は Fig. 4 の ○印に示すようになり，メーカーが通常推奖している

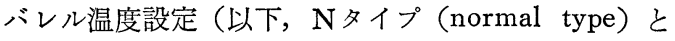
(いう）では, 流出樹脂温度が射出開始直後から時間と 共に単調に高くなり, 結果的に射出中の温度変動が大 きくなっている.

射出成形に及ぼす射出樹脂温度挙動の影響を調べる

Table 1 Molding condition

\begin{tabular}{c|c|c}
\hline Cavity shape $(\mathrm{mm})$ & $\phi 80$ & $\phi 150$ \\
\hline Injection pressure $(\mathrm{MPa})$ & 59.0 & 73.8 \\
Injection speed $(\mathrm{mm} / \mathrm{s})$ & 28.6 & 35.7 \\
Holding pressure $(\mathrm{MPa})$ & 50.2 & 60.5 \\
Mold temperature $\left({ }^{\circ} \mathrm{C}\right)$ & 25 & 25 \\
Clamping force $(\mathrm{kN})$ & 343 & 392 \\
Cycle time $(\mathrm{s})$ & 60 & 80 \\
\hline
\end{tabular}

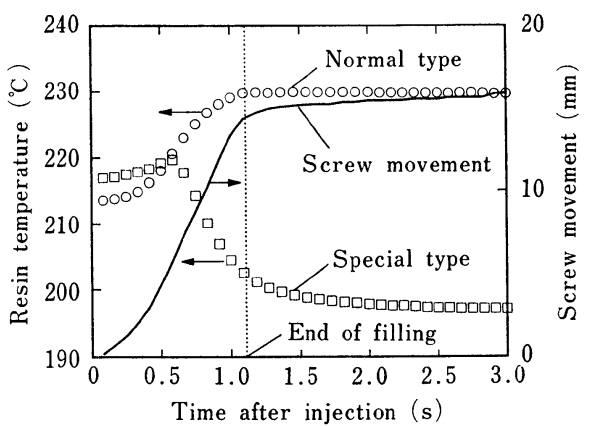

Fig. 5 Behavior of injected resin temperature (Cavity shape $=\phi 80 \mathrm{~mm}$ )

ため，Fig. 4 の口印に示すように射出の初期の樹脂温 度を高く，その後の射出樹脂温度を徐々に低くするよ うにした（以下Sタイプ（special type）という）樹

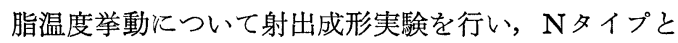
比較検討した。なお， Sタイプのときのバレル設定温 度を Fig. 3 の回印に，ノズルやバレル全体の温度分 布を口印および国印で示す.

さらに, 上記 2 種類のノズルおよびバレル温度分布 状態で，直径 $80 \mathrm{~mm}$ の円盤を成形したときのノズル から金型へ充媜される樹脂の温度挙動を Fig. 5 に示 す. 射出する樹脂の容量を減らした直径 $80 \mathrm{~mm}$ の射 出成形加工に执いても，Fig. 3 亿示すような温度分布 にすると Fig. 4 亿示された温度挙動（直径 $150 \mathrm{~mm}$ ) と類似の挙動を示した.なお， Table 1 に示すように 成形品の形状によって射出成形条件は変化させたが， $\mathrm{N}$ タイプと $\mathrm{S}$ タプでは同一射出成形条件で実験を行 った.

金型内の充填時には良く知られているようにフロー フロントで涌き出し流があるそそのことを考慮して金 型へ充填される樹脂の挙動を極めて簡単なモデルで考 えると Fig. 6 に示すようになる.すなおち，ノズル から充填される樹脂の初期部分が成形品のスキン層を 形成し, 残りの充垍樹脂が成形品のコア部分を形成す る.

Fig. 4 に示される樹脂温度挙動の場合は, ランナー やゲートに近い所と遠い所のコア部分の温度を比較す

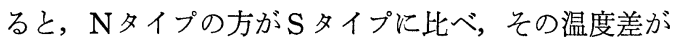
大きくなると考光られる。すすおち, 射出樹脂温度挙 動によって, 成形品の固化状態や結晶化度などの品質 が変化すると考兄られる.

\section{3 実 験 結 果}

\section{a. 結晶化度}

実際に上記 2 種類の射出樹脂温度挙動で, その他の 条件は同じにして成形した、それぞれの成形品につい 


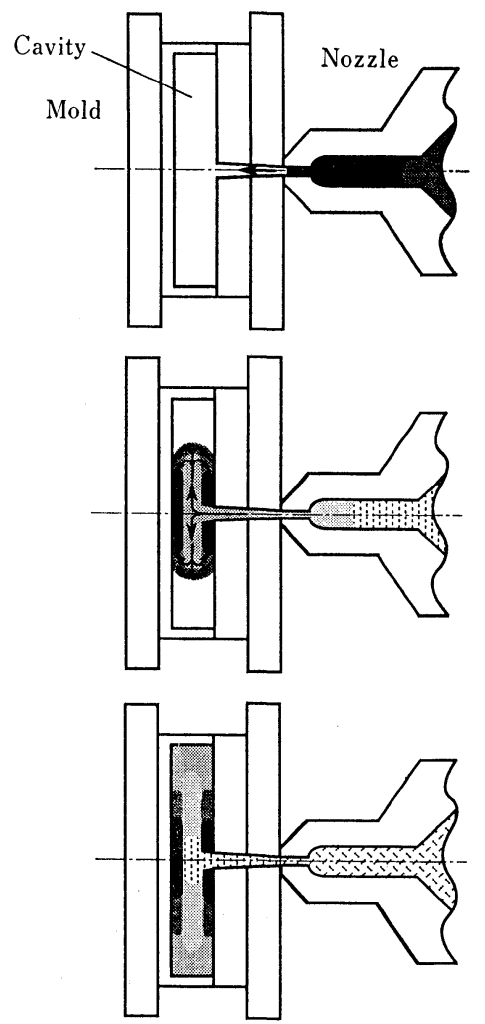

Fig. 6 Schematic flow pattern during filling stage

て, その半径方向の結晶化度分布を測定すると, 直径 150mm の円艋の場合は Fig. 7 に示すように, 直径 $80 \mathrm{~mm}$ の場合は Fig. 8 に示すようになった.

これらの実験に打いて，充填する樹脂温度挙動以外 の射出条件を同じにしても, 成形中の泠却状態やスキ ン層厚さ拉よびせん断速度等がすべて微妙に変化して 成形品の結晶化度へ影響を及ぼしていると考えられ る.したがって正確なことはいえないが，充填完了時 のコア層の温度が高いと結晶化度が高くなると考劣ら れる.すなわち、コア層の樹脂温度が高いほど金型表 面温度の上昇量も大きくなり, 常温まで泠却されるの に要する時間が長くなって, 結果的に結晶化度も高く なると考学らる.したがって，後述（Fig.11参照） のように，充填時に拈いて金型中心付近 $(15 \mathrm{~mm})$ と 外周付近 $(65 \mathrm{~mm})$ の平均温度の差が, $\mathrm{S}$ タイプに比 ベ， $\mathrm{N}$ タイプの方が大きいため， $\mathrm{S}$ タイプの方がより 均一な結晶化度分布となったと考光られる。

な括, 直径 $150 \mathrm{~mm}$ の場合の結晶化度の平均値につ いて考えると， $\mathrm{N}$ タイプの方が $\mathrm{S}$ タイプに比べて高く なっている.これは充填された樹脂の平均温度が高い ためと考兄られる. したがって，Sタイプの結晶化度 の平均値を高くするには, 充媜される樹脂の平均温度

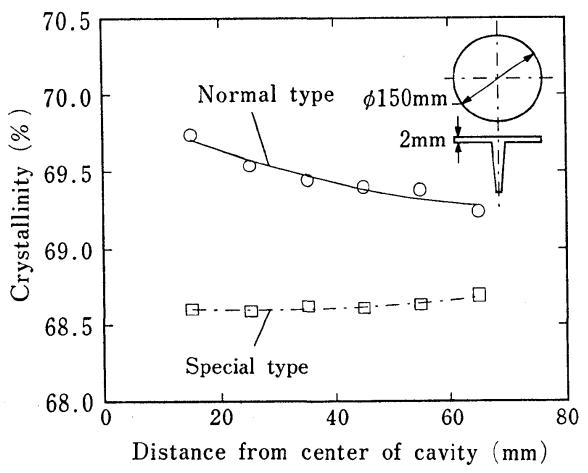

Fig. 7 Crystallinity distribution along the radius (Cavity shape $=\phi 150 \mathrm{~mm}$ )

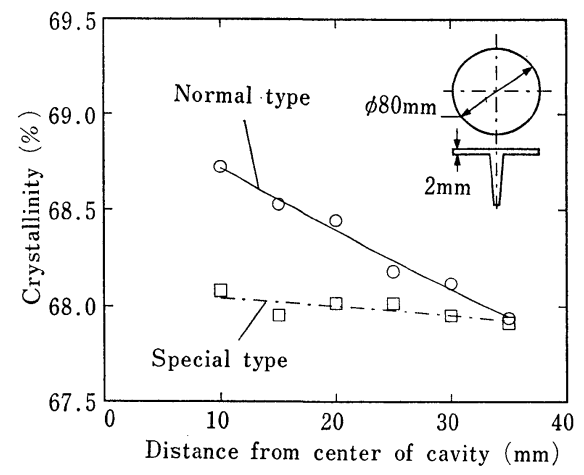

Fig. 8 Crystallinity distribution along the radius (Cavity shape $=\phi 80 \mathrm{~mm}$ )

を高くするか金型温度を上げるかすれば可能であると 考学られる.

\section{b. 固化挙動}

直径 $150 \mathrm{~mm}$ の金型キャビティ内の圧力挙動を測定 すると，Fig. 9 亿示すような結果が得られた. 同図に 示すよらに $\mathrm{S}$ タイプに比べてNタイプの方が, 保圧時 の圧力が高く,かつ遅く低下している.これは, Nタイ プの最後に充媜された樹脂温度が $\mathrm{S}$ タイプの温度に比 べて高くなっているために生じた現象と考兄られる.

そこで，超音波を用いて金型内の固層と溶融層の境 界面で反射して来る超音波の波形からその固化挙動を 調べだ). その結果, Fig. 10 に示すように半径 $65 \mathrm{~mm}$ の位置の方が半径 $15 \mathrm{~mm}$ の位置に比べ固層が速く発

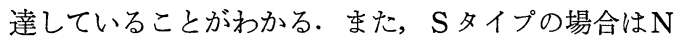
タイプに比べて固層が速く発達していると同時に, 半 径 $15 \mathrm{~mm}$ と $65 \mathrm{~mm}$ とでほぼ同じ速度で固層が発達 している.このことから, 結晶化度がほぼ均一分布に なったものと考兄られる.

また，上述の実験で金型内の樹脂の平均音速を求め ることができる．樹脂の各圧力に打湆速と温度の 


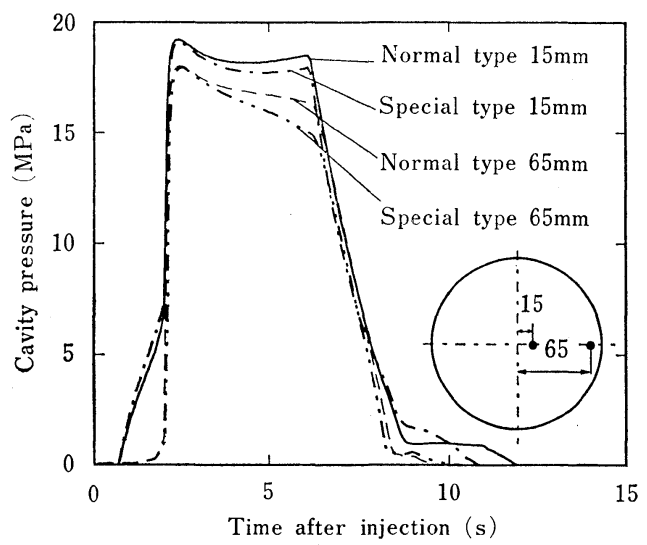

Fig. 9 Pressure behavior in the cavity (Cavity shape $=\phi 150 \mathrm{~mm}$ )

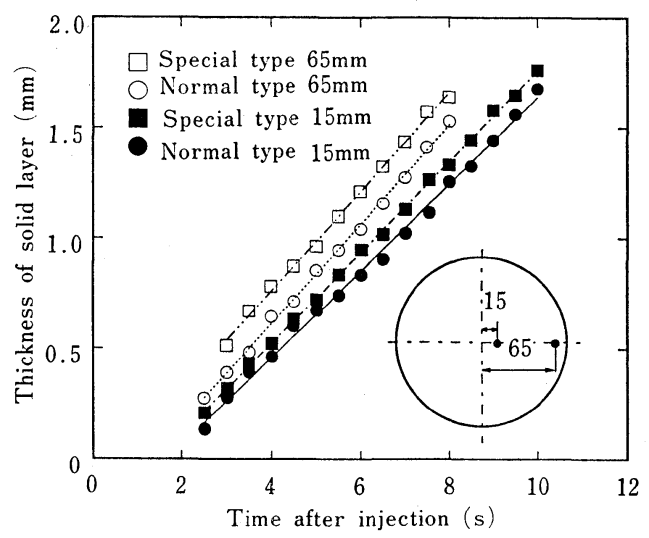

Fig. 10 Thickness of solid layer in the cavity (Cavity shape $=\phi 150 \mathrm{~mm}$ )

関係が明らかにされているので6)，平均音速と圧力の 值から半径 $15 \mathrm{~mm}$ と $65 \mathrm{~mm}$ の位置の平均温度を求 めた。 その結果を Fig. 11 に示す. 同図には，Fig. 9 で示された圧力の挙動を同時に示してある. 同図にお いて半径 $15 \mathrm{~mm}$ の $\mathrm{S}$ タイプの場合, 樹脂の流入直後 より平均温度が低下していくが，充填完了に伴い一時 的に温度低下が止まる挙動を示す．この挙動は金型内 の圧力上昇に伴い，金型内の樹脂が断熱圧縮されて生 じた現象と考兄られる. いっぽう, 同じく半径 $15 \mathrm{~mm}$ の Nタイプの場合は，最初は時間の経過と共に平均温 度が低下するが，充填完了前から平均温度が上昇し， 型内圧力の上昇に伴ってさらに上昇する. 両者の平均 温度挙動の差は, 充塤された樹脂温度挙動の差により 生じたと考觉られる。

\section{c. 金型表面近傍の温度挙動}

射出を開始した時刻をゼロとして，直径 $150 \mathrm{~mm}$ の 金型キャビディ表面近傍（表面から $1 \mathrm{~mm}$ の位置）の

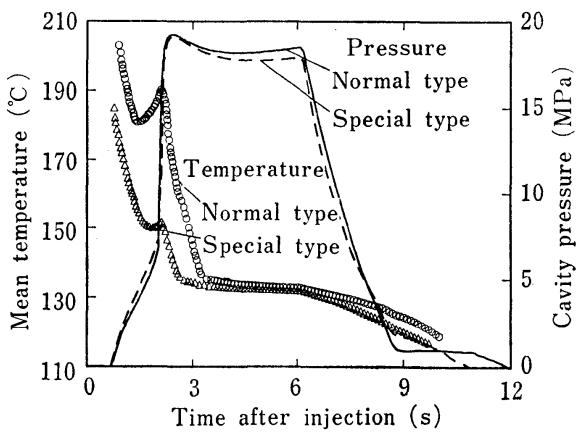

(a) At $15 \mathrm{~mm}$ from center of cavity

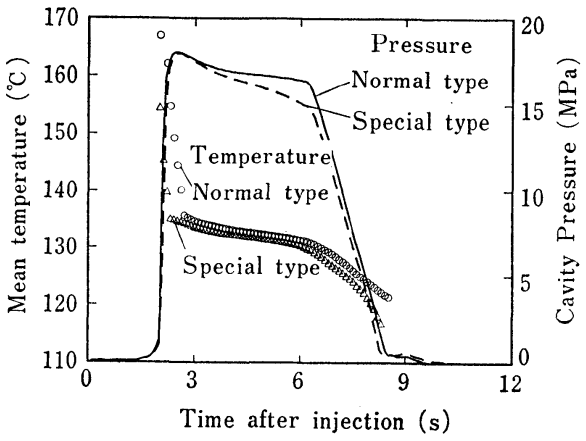

(b) At $65 \mathrm{~mm}$ from center of cavity

Fig. 11 Behavior of mean temperature and cavity pressure

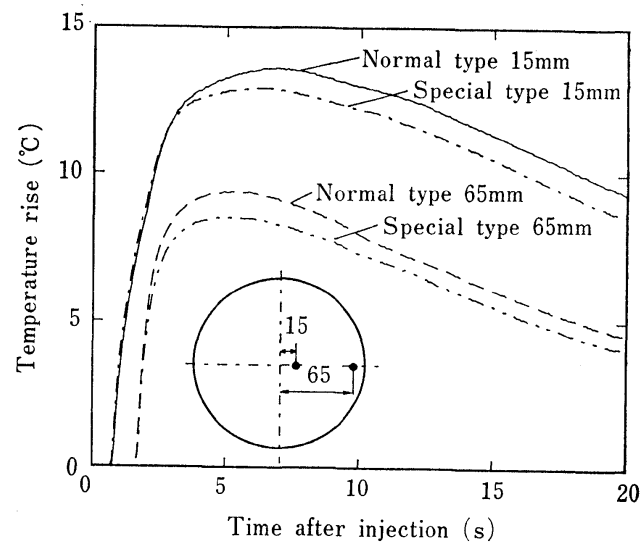

Fig. 12 Mold temperature rise

(Cavity shape $=\phi 150 \mathrm{~mm}$ )

温度上昇量を測定した結果を Fig. 12 に示す. 同図に 示すように，キャビティ中心から半径 $15 \mathrm{~mm}$ と $65 \mathrm{~mm}$ の位置に和ける温度上昇量を比較すると, 半径 $15 \mathrm{~mm}$ の方が高くなり，金型への流入熱量が多いことがわか る.

ここで，充媜された樹脂から金型へ流入する熱流束 の值を半径 $15 \mathrm{~mm}$ の位置で求めた.すなわち，Fig.12 に示される半径 $15 \mathrm{~mm}$ の位置の温度挙動を境界条件 


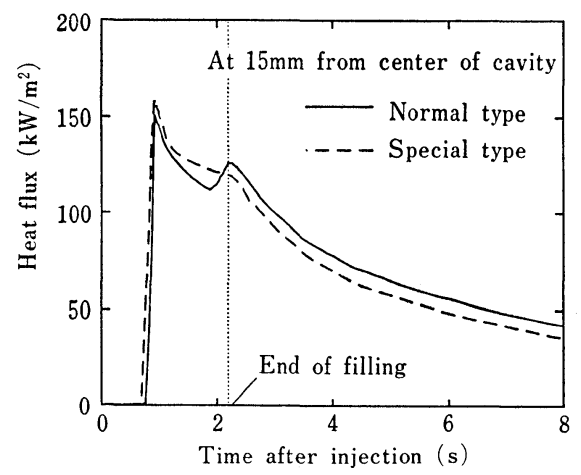

Fig. 13 Behavior of heat flux from filled resin to the cavity wall

(Cavity shape $=\phi 150 \mathrm{~mm}$ )

として，金型内の熱伝導方程式を用いてその熱流束の 值を求めた ${ }^{77}$. その結果を Fig. 13 亿示す. 同図は逆 問題により求めているため, 測定精度がそれほど高く ないが，熱流束の挙動は示していると考学られる.す なわち, Fig. 11 に示したように, Nタイプの場合は 充媜完了直前に樹脂の平均温度が高くなるため, 充填 完了時付近で再び熱流束が増加するといら挙動を示し ている.この結果は, 半径 $15 \mathrm{~mm}$ の位置では, $\mathrm{S}$ タ イプに比べてNタイプの方がコア部の温度が高くなっ ていることを示唆しており,このことからもNタイプ のコア部で結晶化度が高くなった原因が樹脂温度であ ることが確認できる.

\section{3. 結}

\section{言}

ノズルから金型へ充媜される樹脂の温度挙動を熱電 対で測定し，その温度挙動が成形品の冷却・固化状態 へ及汸す影響や成形品の品質の一つである結晶化度分 布へ及ぼす影響につにて調べた結果，以下のようなこ とが明らかとなった。

(1) ノズル内の中心付近に熱電対（直径 $0.5 \mathrm{~mm}$ )を 吹き流しのようにして取り付けることにより，
ズルから射出される樹脂の代表温度を測定するこ とができた。

(2) 従来, 樹脂メーカーで推奖しているようなバレ ル温度分布を用いると，ノズルから金型へ充填さ れる樹脂温度は, 射出前半に比べ, 後半の方が高 くなる傾向がある. その結果, ランナーやゲート に近い部分と遠い部分とでは充填される樹脂温度 および冷却状態が異なり, 結晶化度に差が生じ る. バレルの温度分布を変更してノズルから出る 樹脂温度を変え，射出前半より後半で低くなるよ らにすると，成形品の結晶化度が均一化する傾向 がみられた。この傾向は，射出容量を変化させて も浪渂じになった。すなわち，ノズルから金型 へ充填される樹脂の温度挙動が成形品の品質に密 接に関係していることが明らかとなった。

したがって，本研究で示したように射出される 樹脂温度挙動と成形品の品質の関係がより詳細に 明らかとなれば，さらに高品質の成形品を得るこ とが可能と思われる.

最後に本研究を行らに当たり, 装置の提供および実 験に御協力いただいた新潟鉄工所に感謝する.

\section{参考文 献}

1) Yo, C. J. et al.: Polym. Eng. Sci. 32 (3) 191 (1992)

2) Ludwig, H. J. et al.: Polym. Eng. Sci. 28 (3) 143 (1988)

3) Kudryavtsev, L. and Wang, K. K.: Proc. of SPE ANTEC '93, 88 (1993)

4) Poetsch, G. et al.: Plastverarbeiter, 40 (5) 110 (1989)

5) Amano, O. and Utsugi, S.: Polym. Eng. Sci. 29 (3) 171 (1989)

6）西脇信彦, 崔 愛玲, 今野政昭, 堀 三計：超音 波による金型内樹脂の 固化挙動の 観察「成形加 工」(投稿中)

7) Carslaw, H.S., and Jaeger, J. C.: Conduction of Heat in Solid, 50 (1959) Oxford 